\title{
Qualitative and Quantitative Picture of Innovation in Russia
}

\author{
Liudmila Guzikova \\ St. Petersburg State Polytechnical University, Russia \\ guzikova@mail.ru
}

\begin{abstract}
In the paper the general characteristic of innovative activity in Russia is given, the factors of innovation are identified; the performance indicators of innovation are determined; the qualitative relations between the factors and performance indicators of innovation are identified; the models of quantitative analysis of relation between the factors and performance indicators of innovation are proposed; the proposed models are applied to receive quantitative characteristics; the current state, prospects and development priorities of innovation in Russia are assessed.
\end{abstract}

Keywords: Innovation, Innovative development, Innovation indicators

\section{Introduction}

At the present stage of global development innovation is considered as a crucial factor of national economic competitiveness. Innovation is not perceived as individual act with limited space and time effects, but as a continuous and comprehensive managed process leading to irreversible changes in the socio- economic sphere. Business entities, focused on long-term existence and development, should participate in this process. Being similar in objectives, content and its main directions innovation in Russia differs of that in other countries due to the unique set of specific features determined by sectoral structure of economy; large variety of natural, climatic and socio-economic circumstances in regions; post-privatization changes in economy; structure of external economic activity; forms and methods of governmental participation in economics; ratio between large and small businesses; structure and current state of financial system; legal status of intellectual property; current state and potential of research and development; traditions and current state of education system etc.

\section{Methodology}

The research methodology includes:

- analysis of theoretical and applied scientific publications on financial-economic aspects of innovation;

- $\quad$ analysis of current media information on innovation in Russia;

- $\quad$ analysis of state statistics by comparisons and identifying structural and tempo proportions.

The official statistics on innovation is conducted in Russia since 2009. At the time of current study the data were available for 2012 on the site of the state statistics.

\section{The main provisions and results}

In the list Most Innovative in the World 2014 published by Bloomberg ranking in January 2014 Russia occupied the 18th place. Compared to that in 2013 when Russia had the 14th place this result may be interpreted in whole as deterioration. Bloomberg ranked countries and sovereigns based on their overall ability to innovate. Seven weighted factors of innovative activity were considered and their scores combined to provide an overall score for each country from zero to 100 (Lu \& Chan,2014):

- $\quad$ R\&D intensity (20\% of score). Research and development expenditure as a percentage of GDP;

- $\quad$ Productivity (20\%). GDP per employed person age 15 and over;

- High-tech density (20\%). Number of high-tech public companies - such as aerospace and defense, biotechnology, hardware, software, semiconductors, Internet software and services, and renewable energy companies - as a percentage of all publicly listed companies 
- Researcher concentration (20\%). Professionals, including Ph.D. students, engaged in R\&D per 1 million people.

- Manufacturing capability (10\%). Manufacturing value-added as a percentage of GDP and as a share of world total manufacturing value-added.

- Tertiary efficiency (5\%). Number of secondary graduates enrolled in postsecondary institutions as a percentage of cohort; percentage of labor force with tertiary degrees; annual science and engineering graduates as a percentage of the labor force and as a percentage of total tertiary graduates.

- Patent Activity (5\%). Resident patent filings per 1 million residents and per $\$ 1$ million of R\&D spent; patents granted as a percentage of the world total.

Figure 1 allows compare Russia with the countries occupying three leading positions - South Korea, Sweden and United States - by separate factors.

Figure 1: Ranking of Russia relatively to the leading innovative countries

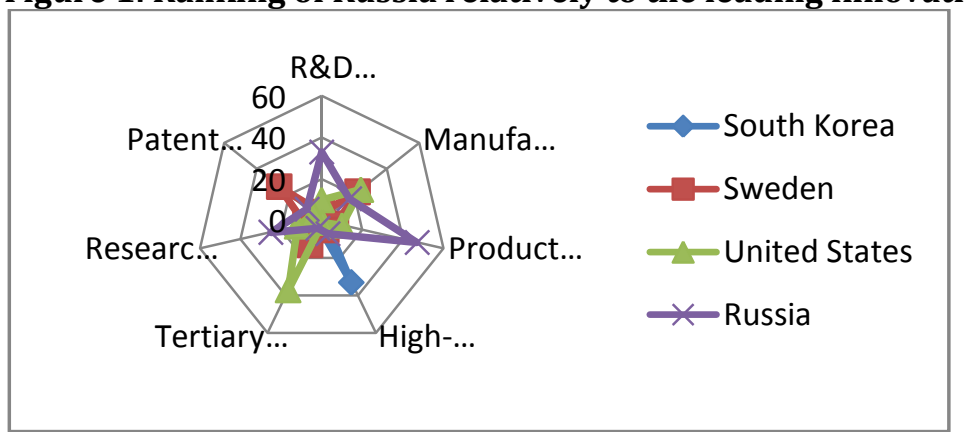

It may be noted that the country improved relative positions in Manufacturing capability, High-tech density and Tertiary efficiency, whereas positions became slightly worse in R\&D intensity and Patent activity and significantly worse in Productivity and Researcher concentration (Tab. 1).

Table 1: Separate ranks of Russia in the ranking Most Innovative in the World

\begin{tabular}{lccccccc}
\hline Year & $\begin{array}{c}\text { R\&D } \\
\text { intensity } \\
\text { rank }\end{array}$ & $\begin{array}{c}\text { Manufacturin } \\
\text { g capability } \\
\text { rank }\end{array}$ & $\begin{array}{c}\text { Productivity } \\
\text { rank }\end{array}$ & $\begin{array}{c}\text { High-tech } \\
\text { density } \\
\text { rank }\end{array}$ & $\begin{array}{c}\text { Tertiary } \\
\text { efficiency } \\
\text { rank }\end{array}$ & $\begin{array}{c}\text { Researcher } \\
\text { concentration } \\
\text { rank }\end{array}$ & $\begin{array}{c}\text { Patent } \\
\text { activity } \\
\text { rank }\end{array}$ \\
\hline 2013 & 29 & 41 & 2 & 24 & 38 & 2 & 8 \\
2014 & 33 & 17 & 47 & 7 & 4 & 25 & 9 \\
Direction & $\downarrow$ & $\uparrow$ & $\downarrow$ & $\uparrow$ & $\uparrow$ & $\downarrow$ & $\downarrow$ \\
of change & $\downarrow$ & & & & & & $\downarrow$ \\
\hline
\end{tabular}

Funding of R\&D: Governmental support of innovation activities In Russia is carried out mainly by channeling financial resources for the implementation of federal target programs and targeted investment to R\&D, approved by the resolution of the Government of the Russian Federation. These programs include research, development, production, socio-economic, organizational, economic and other measures to ensure the effective solution of public, economic, environmental, social and cultural development problems of Russian Federation. All elements of programs are coordinated by resources and implementation timeframes. The dynamics and the structure of expenditures of the Federal Government on R\&D are shown in Tab.3. In spite of the fact that the assigned sum increased by $62.48 \%$ since 2008 its share in federal budget and in GDP did not changed visibly. The evident tendency is the decrease of expenditures share on fundamental research. This fact may be explained by the ambition to get the results in short term period. The share of governmental funding on fundamental research reduced in 2012 to $24.34 \%$. 
Figure 2: The structure of internal R\&D funding

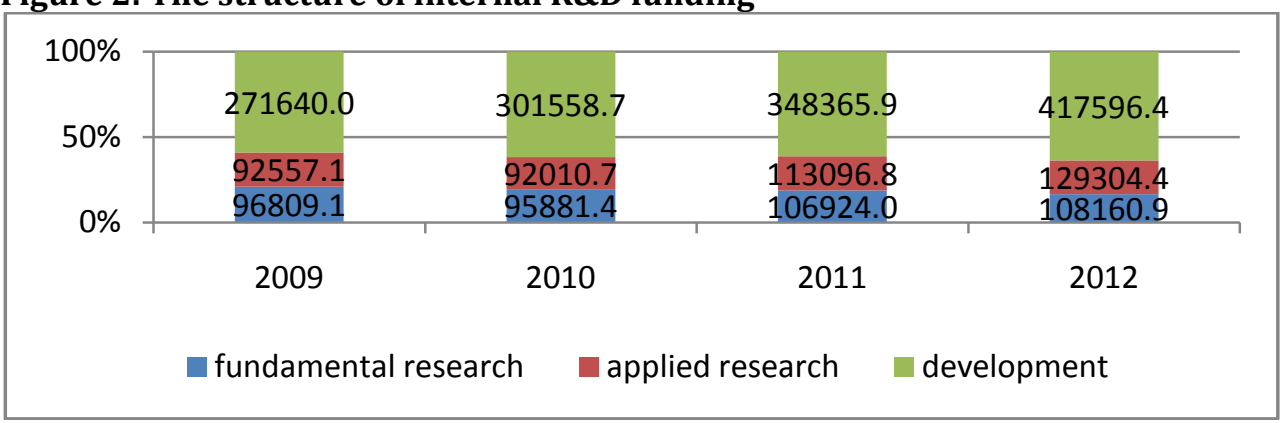

In Table 2 the basic indicators of state statistics characterizing innovative development of Russia are presented.

Table 2: Indicators of innovative activity in Russia in 2009-2012 (Federal State Statistics Service, 2014)

\begin{tabular}{|c|c|c|c|c|}
\hline Indicator & 2009 & 2010 & 2011 & 2012 \\
\hline $\begin{array}{l}\text { Innovative activity of organizations (the share of } \\
\text { organizations implementing technological, } \\
\text { organizational and marketing innovations in the } \\
\text { total number of organizations), } \%\end{array}$ & 9.3 & 9.5 & 10.4 & 10.3 \\
\hline $\begin{array}{l}\text { Share of organizations implementing technological } \\
\text { innovation in the total number of organizations, } \%\end{array}$ & 7.7 & 7.9 & 8.9 & 9.1 \\
\hline $\begin{array}{l}\text { Shipped products of own production, works and } \\
\text { services in their own, million rub. }\end{array}$ & 20711959.3 & 25794618.1 & 33407033.4 & 35944433.7 \\
\hline $\begin{array}{l}\text { Including innovative products, works, services, } \\
\text { million rub. }\end{array}$ & 934589.0 & 1243712.5 & 2106740.7 & 2872905.1 \\
\hline $\begin{array}{l}\text { The share of innovative products, works and } \\
\text { services in the total volume of shipped products, } \\
\text { works, services, \% }\end{array}$ & 4.5 & 4.8 & 6.3 & 8.0 \\
\hline \multicolumn{5}{|l|}{$\begin{array}{l}\text { Expenditure on technological innovation, million } \\
\text { rub. }\end{array}$} \\
\hline in actual prices & 399122.0 & 400803.8 & 733815.9 & 904560.8 \\
\hline in constant prices of 2000 & 114999.7 & 101124.6 & 160298.7 & 182117.2 \\
\hline $\begin{array}{l}\text { Expenditure on technological innovation in the total } \\
\text { volume of shipped products, works, services, } \%\end{array}$ & 1.9 & 1.6 & 2.2 & 2.5 \\
\hline $\begin{array}{l}\text { The share of organizations implementing } \\
\text { organizational innovations in the total number of } \\
\text { organizations, } \%\end{array}$ & 3.2 & 3.2 & 3.3 & 3.0 \\
\hline $\begin{array}{l}\text { The share of organizations implementing marketing } \\
\text { innovation in the total number of organizations, } \%\end{array}$ & 2,1 & 2,2 & 2,3 & 1,9 \\
\hline $\begin{array}{l}\text { The share of organizations implementing } \\
\text { environmental innovations in the total number of } \\
\text { organizations, \% }\end{array}$ & 1,5 & 4,7 & 5,7 & 2,7 \\
\hline
\end{tabular}

Table 3: Governmental expenditures on R\&D in 2009 - 2012

\begin{tabular}{|c|c|c|c|c|}
\hline & 2009 & 2010 & 2011 & 2012 \\
\hline $\begin{array}{l}\text { Total expenditures of the Federal Governme } \\
\text { on civil science, million rub. } \\
\text { including }\end{array}$ & 219057.6 & 237644.0 & 313899.3 & 355920.1 \\
\hline Fundamental research & 83198.1 & 82172.0 & 91684.5 & 86623.2 \\
\hline Applied research & 135859.5 & 155472.0 & 222214.8 & 269296.9 \\
\hline The share of expenditures on applied research & $62.02 \%$ & $65.42 \%$ & $70.79 \%$ & $75.66 \%$ \\
\hline Percent of federal budget expenditures & 2.27 & 2.35 & 2.87 & 2.76 \\
\hline Percent to GDP & 0.56 & 0.51 & 0.56 & 0.56 \\
\hline
\end{tabular}

The tendency of decrease the fundamental research funding appears also in the allocation of internal expenditures on scientific activity (Figure 2). 
Total internal expenditures on R\&D increased in 2012 compared to 2009 by $42.09 \%$ and constituted 699869.8 million rub. For one staff member of R\&D organizations the expenditures average value constitutes 963.5 thousand rub. annually. The structure of R\&D internal expenditures did not changed significantly during the observed period. In 2012 the compensation constituted 47\% of total amount. Together with the mandatory assessed payments it constitutes 58.51\% (Fig. 3). The minimal share $(3.87 \%)$ belongs to purchase of equipment. It shows that the opinion that purchase of modern equipment can provide the big jump in the development of Russian R\&D does not come true.

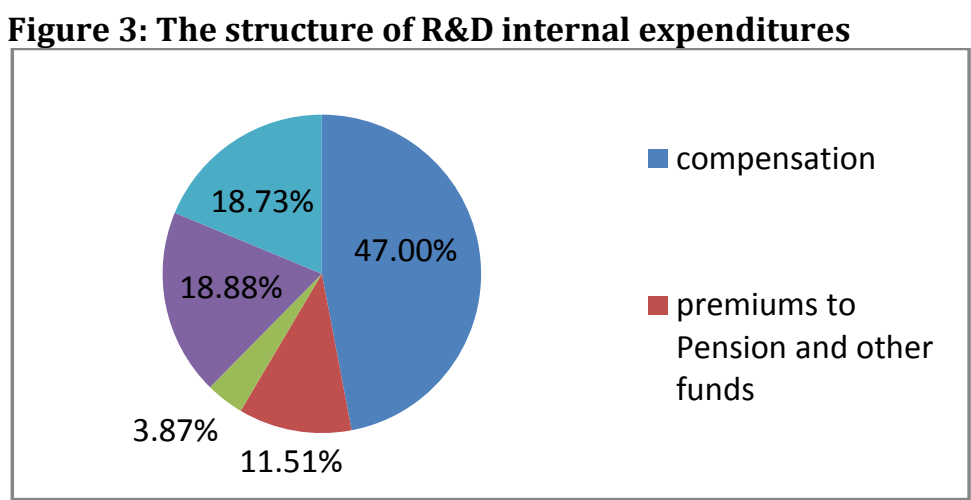

Regional aspect of innovations: Regions of Russia vary significantly by the innovative factors' impact on their development. The most important sources of differences is the uneven level of competitive institutes - R\&D base, industrial culture, public authority, the degree of freedom and confidence of economic agents.

Figure 4: The regional structure of shipped products, works and services in 2012

$20.14 \%$\begin{tabular}{c|}
$20.75 \%$ \\
Central Federal District \\
No.97\%
\end{tabular}
Northwestern Federal District
Southern Federal District
The North Caucasus Federal District
Volga Federal District

The half of the total number of R\&D organizations are situated in Central (including Moscow) and Northwestern (including Saint-Petersburg)| Federal Districts (Figure 5).

Figure 5: The regional allocation of R\&D organizations in 2012

$6.62 \% \frac{11.89 \%}{2.78 \%} 13.66 \%$
$\quad$ Central Federal District
Northwestern Federal District
Southern Federal District

The North Caucasus Federal District


Figure 6 and Figure 7 allow compare the regional structure of R\&D internal expenditures and shares of shipped innovative products, works and services.

Figure 6: The regional structure of R\&D internal expenditures in 2012

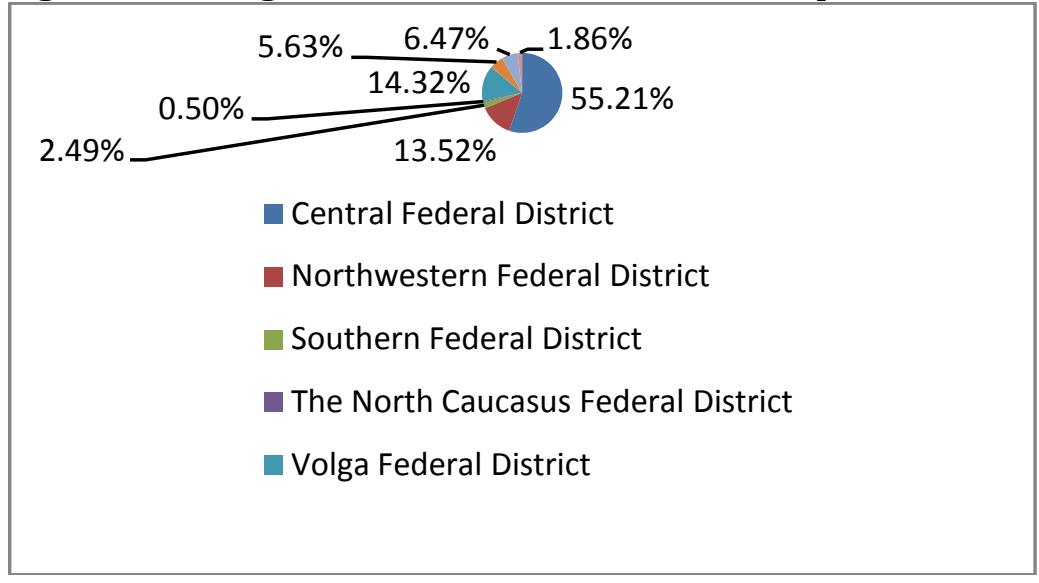

The united share of Central and Northwestern Federal Districts in total amount of internal expenditures is equal to $68.63 \%$, but their share in total amount of shipped products, works and services is constitutes only $33.04 \%$.

Figure 7: The regional structure of shipped innovative products, works and services in 2012

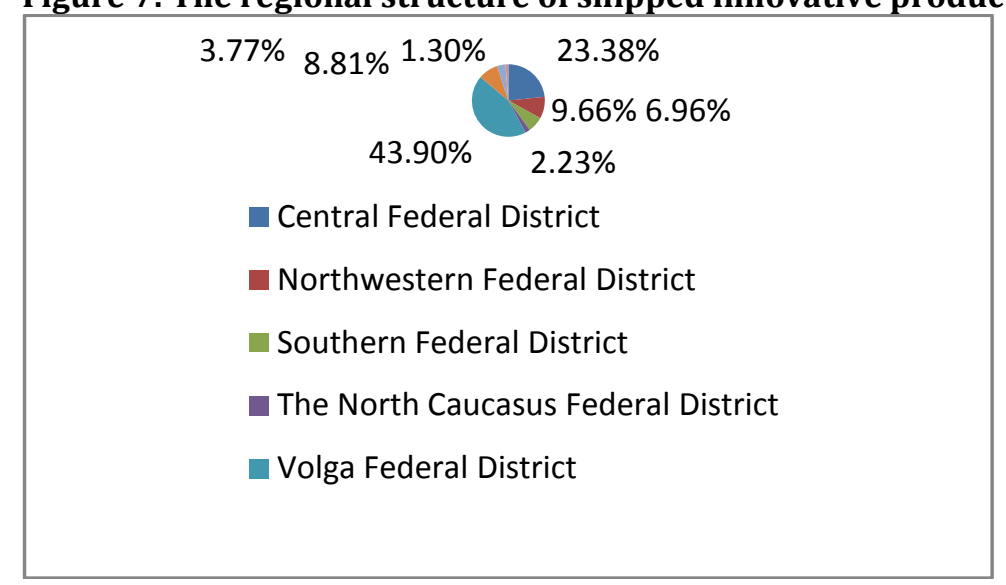

Table 4: Regional revenue and R\&D internal expenditures in 2012

\begin{tabular}{|c|c|c|c|c|c|}
\hline Region & $\begin{array}{l}\text { Shipped } \\
\text { products, } \\
\text { works and } \\
\text { services, } \\
\text { million rub. }\end{array}$ & $\begin{array}{l}\text { Shipped } \\
\text { innovative } \\
\text { products, } \\
\text { works and } \\
\text { services, } \\
\text { million rub. }\end{array}$ & $\begin{array}{l}\text { R\&D internal } \\
\text { expenditures }\end{array}$ & $\begin{array}{l}\text { The share of } \\
\text { innovative } \\
\text { products, } \\
\text { works and } \\
\text { services, } \%\end{array}$ & $\begin{array}{l}\text { Revenue from } \\
\text { innovative } \\
\text { products, } \\
\text { works and } \\
\text { services to } \\
\text { R\&D } \\
\text { expenditures, } \\
\text { rub. / rub. }\end{array}$ \\
\hline Russia & 35944433.7 & 2872905.1 & 699869.8 & 7.99 & 4.10 \\
\hline Central Federal District & 9172759.5 & 938153.2 & 369069.5 & 10.23 & 2.54 \\
\hline $\begin{array}{l}\text { Northwestern } \quad \text { Federal } \\
\text { District }\end{array}$ & 4095204.7 & 298020.1 & 100002.7 & 7.28 & 2.98 \\
\hline Southern Federal District & 1731151.0 & 51801.6 & 18618.0 & 2.99 & 2.78 \\
\hline $\begin{array}{l}\text { The North Caucasus } \\
\text { Federal District }\end{array}$ & 347998.3 & 27010.1 & 3448.1 & 7.76 & 7.83 \\
\hline Volga Federal District & 7458276.8 & 950604.8 & 109155.0 & 12.75 & 8.71 \\
\hline Urals Federal District & 7239168.9 & 148696.2 & 40420.2 & 2.05 & 3.68 \\
\hline Siberian Federal District & 4390819.8 & 117118.0 & 47011.7 & 2.67 & 2.49 \\
\hline $\begin{array}{l}\text { Far Eastern Federal } \\
\text { District }\end{array}$ & 1509054.7 & 341501.1 & 12144.6 & 22.63 & 28.12 \\
\hline
\end{tabular}


It should be mentioned that correlation ratio between the amounts of innovative production, works and services and the amount of R\&D internal expenditures increased since 2009 from 0.52 to 0.77 in 2012 . The ratio of revenue from innovative products, works and services to R\&D internal expenditures can be interpreted as an indicator of R\&D performance. In Tab. 4 it may be seen that according to the share of innovative production the most innovative regions are Far Eastern, Volga and Central Federal Districts. But according to criterion of revenue from innovation to R\&D expenditures the third place after Far Eastern and Volga Federal Districts occupies North Caucasus Federal District whereas Central alongside with Siberian Federal District has the value of this indicator few times lower.

Productivity: It is necessary to mention that innovation in Russia are usually considered from the standpoint of new products, works and services and are often estimated exclusively by their natural and monetary volume.

a) The author believes that innovation is not the result of manufacturing any products that is usually associated with high-tech products but continuous increase of the performance of economy and sustainable improvement of the life quality. The standpoint that innovative economy is an economy which is constantly improving productivity, increasing total factor productivity and any processes leading to higher performance, accelerating the growth of economy, increasing GDP per capita may be called innovative is represented by some Russian and foreign economists and governmental officials (Shumpeter, 1982; Drobyishevskiy, 2011).

b) In Global rating of economies published by World Bank in July 2013 GDP per capita constituted in Russia \$12700 in 2012. For comparison in the countries leaders in Most Innovative in the World GDP per capita was equal in South Korea $\$ 22670$, in Sweden $\$ 55970$ in the United States $\$ 52340$. It may be mentioned that estimations of GDP in Russian accounting purchasing power rarity are higher but they differ depending on their sources.

Table 5: Basic indicators of innovative activity in the sectors of Russian economy in 2012

\begin{tabular}{|c|c|c|c|}
\hline Indicator & Total & Sector A & Sector B \\
\hline $\begin{array}{l}\text { Innovative activity of organizations (the share of } \\
\text { organizations implementing technological, } \\
\text { organizational and marketing innovations in the total } \\
\text { number of organizations), } \%\end{array}$ & 10.3 & 11.1 & 9.0 \\
\hline $\begin{array}{l}\text { Share of organizations implementing technological } \\
\text { innovation in the total number of organizations, } \%\end{array}$ & 9.1 & 9.9 & 8.0 \\
\hline $\begin{array}{l}\text { Shipped products of own production, works and } \\
\text { services in their own, million rub. }\end{array}$ & 35944433.7 & 32153385.6 & 3791048.2 \\
\hline $\begin{array}{l}\text { Including innovative products, works, services, } \\
\text { million rub. }\end{array}$ & 2872905.1 & 2509604.4 & 363300.8 \\
\hline $\begin{array}{l}\text { The share of innovative products, works and services } \\
\text { in the total volume of shipped products, works, } \\
\text { services, } \%\end{array}$ & 8.0 & 7.8 & 9.6 \\
\hline Expenditure on technological innovation, million rub. & 904560.8 & 583660.6 & 320900.3 \\
\hline $\begin{array}{l}\text { Expenditure on technological innovation in the total } \\
\text { volume of shipped products, works, services, } \%\end{array}$ & 2.5 & 1.8 & 8.5 \\
\hline The share of organizations implementing & & & \\
\hline $\begin{array}{l}\text { organizational innovations in the total number of } \\
\text { organizations, } \%\end{array}$ & 3.0 & 3.2 & 2.6 \\
\hline $\begin{array}{l}\text { The share of organizations implementing marketing } \\
\text { innovation in the total number of organizations, } \%\end{array}$ & 1.9 & 2.2 & 1.6 \\
\hline $\begin{array}{l}\text { The share of organizations implementing } \\
\text { environmental innovations in the total number of } \\
\text { organizations, } \%\end{array}$ & 2.7 & 3.4 & 1.5 \\
\hline
\end{tabular}

High-tech density: The statistical compilations classify as high-tech industry the following sectors: production of pharmaceutical products; manufacture of office machinery and computers; manufacture of radio, television and communication equipment; manufacture of medical, precision and optical instruments, watches; manufacture of aircraft and spacecraft. In 2013 the rating of innovative companies was organized by RVC, the Association of Innovative Regions of Russia (AIRR), Vnesheconombank and 
PwC. The requirements companies must meet included the following: the revenue not less than 100 million rub., but not more than 10 billion rub.; the average annual revenue growth of at least $15 \%$; the share of the average R\&D and technological innovation expenditures from $2 \%$ to $10 \%$ of revenue for various industries; successful launch in the market at least one new product or service based on their own intellectual development. Revenue from sales of such innovative products should average at least $30 \%$, depending on the industry. Top 10 included $4 \mathrm{f}$ companies of Information and Communication Technologies, 3 companies of Pharmaceuticals and medical equipment and 3 companies of engineering, instrument and electrical engineering. 4 companies are allocated in Central, 3 in Northwestern, 2 in Volga and 1 in Siberian Federal Districts. Tab. 5 shows the basic indicators of two important sectors of Russian economy - traditional sector of extraction of mineral resources; manufacturing, production and distribution of electricity, gas and water (Sector A) and high technological sector of communication; activities related to the use of computer and information technologies; research and development; the provision of other services (Sector B) - compared to average values of economy in 2012. The cells of the table containing the values of indicators exceeding average value are indicated by color. The result seems paradoxical as traditional Sector A looks much more innovative than modern Sector B. The ratio of revenue of innovative products, works, services to expenditures on technological innovation in average equals to 3.18, in sector A to 4.20 and in Sector B to 1.13 that confirms the higher performance of innovations in traditional sector.

Researcher concentration: The estimation of researcher concentration can be achieved by dividing the total number of R\&D personnel without adding PhD students as the most part of them participate in scientific activity as the staff members of R\&D organization. The share of R\&D personnel constituted about $0.51 \%$ of total population of Russia in 2012. The share of researchers (without accounting technicians and supporting staff) constituted $0.21 \%$.

Manufacturing capability: GDP of Russia was equal to 62600 billion rub. in 2012. Added value constituted $86 \%$ of GDP. The share of Russia in world economy was equal to $4.1 \%$., bur the share in world added value - only $2.1 \%$ that demonstrate low efficiency of Russian economy. Sector structure of added value is presented in Fig.8. The main share of value added was created in Wholesale \& Retail - 20\%. In manufacturing sector $15 \%$ of added value were created and in extraction of mineral resources $11 \%$.

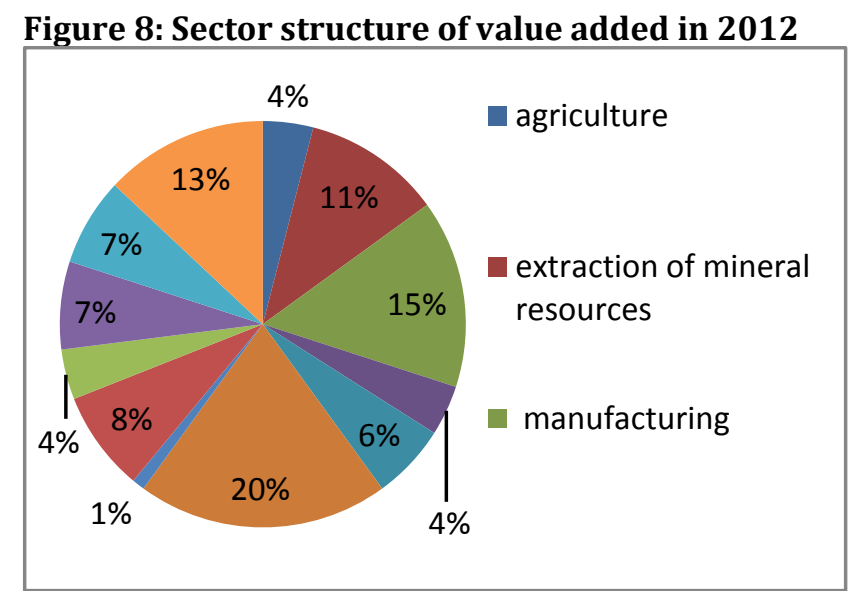

Tertiary efficiency: The system of the highly qualified personnel training in Russia differs of those in other countries as there are two levels of higher scientific qualification - the first is Candidate of Sciences (approximately corresponds to $\mathrm{PhD}$ degree) and the second is Doctor of Sciences. So for the tertiary efficiency estimation the total number of PhD and doctoral students should be taken into account In 2012 total number of researchers with higher scientific qualification included 81546 Candidates of Sciences and 27784. The share of the personnel with higher scientific qualification in total number of R\&D organizations staff constituted $15 \%$, but in the total number of researchers its share equaled to $29 \%$. In 20129195 Candidates of Sciences and 394 Doctors of Sciences graduated and got the appropriate degrees. 
Patent activity: The number of patent applications filed in 2012 was equal to 44211 that is by $14.64 \%$ more than in $2011.64 .02 \%$ of the filed patent applications are the proposals of Russian applicants. The share of Russian applicants in total number of approved application is equal to $68.37 \%$. The utility models constitute the most part of approved applications.

\section{Prospects of Innovative development in Russia}

Innovative economy in Russia is a clearly defined priority of national development. It is supported by the set of concrete measures. In particular, a presidential commission on modernization and technological development of the economy was established for study of the topical issues hi-tech industry. Also the Government Commission on High Technology and Innovation was established. The decisions of these bodies determine the legislative measures aimed at stimulating innovation processes. Russian researchers suggest two models of innovative development of Russia:

- modernization strategy - development of Russian economy through the modernization and adaptation of technologies developed and cultivated in foreign countries (Polterovich, 2009):

- technological breakthrough strategy - the development priority of industry emerging sixth technological orders (Glazev, 2009).

The current concept of socio-economic development is based on innovation scenario. Along with a competitive advantage in traditional sectors (energy, transport and agricultural sector), and the new high-tech sectors of the knowledge economy this scenario assumes the breakthrough in improving the efficiency of human capital, development of high-and medium technology industries. The innovation factors should become the main source of economic growth. According to this concept the economic growth rate to 2020 will constitute $106.5 \%$. Implementing innovative scenario would achieve the level of socio -economic development, characteristic for developed post-industrial countries, due to: development and implementation of the comparative advantages of the economy in energy, science and education, high-tech and other sectors; dynamics of institutions that determine business and investment activity and competitiveness of companies; intensity of the manufacturing industries innovative renewal and the dynamics of labor productivity; dynamics of transport and energy infrastructure; intensity of the human capital quality improvement and the formation of the middle class; integration of the Euro-Asian Economic Space. GDP by 2020 must increase by 2.3 times compared with 2007, real disposable income 2.6 times, poverty would be reduced to 6.2 percent. According to international economic organizations the depreciation of fixed assets in the Russian economy is estimated at a minimum of $50 \%$. The depreciation of fixed assets of power plants to date exceeds $40 \%$, in power machine building - more than $55 \%$, and in some regions it is close to $70 \%$, in the other branches of machine building - close to $70 \%$, in the agricultural sector and forest industry - from 55 to $70 \%$. Improving labor productivity is usually regarded as a result of innovation, but initially low productivity becomes an obstacle of innovation. Tab. 6 provides information on labor productivity in the US and Russia. The largest gap has place in traditional industries. In the field of high technology it is less - labor productivity in Russia is equal to $64.71 \%$ of that in the US.

Table 6: Annual output per worker, million \$ (Levinskiy, 2013)

\begin{tabular}{lll}
\hline Sector & US & Russia \\
\hline Oil and gas & 5 & 0.52 \\
Metallurgy & 0.57 & 0.15 \\
Retail & 0.23 & 0.16 \\
Construction & 0.56 & 0.14 \\
Agriculture & 0.55 & 0.21 \\
Electric Power & 0.79 & 0.20 \\
Software Development and Information Technology & 0.51 & 0.33 \\
\hline
\end{tabular}

The lack of own investment resources, the difficulties of access to debt funding in combination with the desire to make a profit in the short term at minimum cost force the businesses to replace sophisticated technology by unskilled labor. The owners of dominant corporations are not interested in long-term development. It should be mentioned that the replacement of machines by living labor reduces the unemployment rate in the country, but does not contribute to the life level improvement. Low transparence of innovative sphere also prevents the demand growth on innovative products, works and 
services. Research conducted by patent organizations show that only few Russian companies are ready to disclose the essence of their innovation projects.

\section{Conclusion}

- The weaknesses of innovation in Russia are the increase of R\&D intensity, patent activity, productivity and researcher concentration.

- Macroeconomic indicators responsive to innovation include GDP, gross value added, the structure of the gross value added, labor productivity and the unemployment level.

- Currently, the process of replacement of machinery by living labor prevails over the release of workers as a result of innovation that allows preventing unemployment creation.

- Technologically backward industry can't form a demand for the high level innovation. It is necessary to conduct industrial policy promoting effective demand for high-tech products in the scale of the national economy.

- In Russia the influence of high-tech sectors on these indicators is small compared with the innovations in the traditional sectors of the economy.

- The main problems in Russian economy that must be solved for the successful transition to innovative development scenario: accelerated renewal of fixed capital; improving labor productivity; expansion of the domestic market of high technology products.

\section{References}

Drobyishevskiy, S. (2011). Igroki: Innovatsionnoy ekonomiki ne budet bez sprosa na innovatsii. Gazeta Vedomosti, prilozhenie «Forum». http://i-russia.ru/all/articles/5193 (accessed on April 15, 2014).

Federal State Statistics Service. (2014). http: www.gks.ru (accessed on April 15, 2014).

Glazev, S. (2009). Modernizatsiya rossiyskoy ekonomiki na osnove novogo tehnologicheskogo uklada kak klyuchevoe napravlenie antikrizisnoy politiki // Analiticheskie dokladyi pobediteley konkursa «Rossiya v usloviyah mirovogo krizisa». M.: RGNF; Yazyiki slavyanskih kultur.

Levinskiy, A. (2013). V kakih otraslyah rabotayut samyie neeffektivnyie rossiyskie kompanii. http://www.forbes.ru/kompanii/245905-v-kakikh-otraslyakh-rabotayut-samyeneeffektivnyerossiiskie- kompanii Forbes (accessed on April 15, 2014).

Lu, W. \& Chan, M. (2014). In Global Innovation Race, Taiwan Is Tops in Patents, Israel Leads in R\&D. http://www.bloomberg.com/news/2014-01-22/in-global-innovation-race-taiwan-is-tops-inpatents-israel-leads-in-r-d.html (accessed on April 15, 2014).

Polterovich, V. (2009). Strategiya modernizatsii: vyihod iz krizisa na traektoriyu byistrogo ekonomicheskogo rosta. Analiticheskie dokladyi pobediteley konkursa «Rossiya v usloviyah mirovogo krizisa». M.: RGNF; Yazyiki slavyanskih kultur. pp. 229-251

Shumpeter, Y. (1982). Teoriya ekonomicheskogo razvitiya. M.: Progress. 